Abstracta Iranica

Revue bibliographique pour le domaine irano-aryen

Volume 32-33 | 2013

Comptes rendus des publications de 2009-2010

\title{
Daniel Blow. Shah Abbas. The Ruthless King Who Became an Iranian Legend
}

Jean Calmard

\section{Q OpenEdition \\ 1 Journals}

\section{Electronic version}

URL: http://journals.openedition.org/abstractairanica/40647

DOI: 10.4000/abstractairanica.40647

ISSN: 1961-960X

Publisher:

CNRS (UMR 7528 Mondes iraniens et indiens), Éditions de l'IFRI

\section{Printed version}

Date of publication: 1 December 2013

ISSN: 0240-8910

\section{Electronic reference}

Jean Calmard, «Daniel Blow. Shah Abbas. The Ruthless King Who Became an Iranian Legend ", Abstracta Iranica [Online], Volume 32-33 | 2013, document 234, Online since 01 July 2016, connection on 03 October 2020. URL : http://journals.openedition.org/abstractairanica/40647 ; DOI : https://doi.org/ 10.4000/abstractairanica.40647

This text was automatically generated on 3 October 2020 .

Tous droits réservés 


\title{
Daniel Blow. Shah Abbas. The Ruthless King Who Became an Iranian Legend
}

\author{
Jean Calmard
}

\section{REFERENCES}

Daniel Blow. Shah Abbas. The Ruthless King Who Became an Iranian Legend. London-New York, I.B. Tauris, 2009, 247 p., illustrations in black white and colors, bibl., index.

1 According to the author's preface, "this book addresses the general reader". Blow pays homage to the "immense amount of scholarly work" done on the Safavid period over the past three or four decades. While concentrating on the eventful history of Shah Abbas, this book encompasses, in twenty chapters, the whole span of Safavid history from "Shah Abbas's inheritance: The birth of a Shi'i state" (chapter 1) to "The later Safavids" (chapter 20). Reflecting recent scholarship, this biography fills a gap in Iranian history, but it is not devoid of shortcomings, approximations and errors. From the outset, no mention is made of the "takeover" by Safī al-Dīn (founder of the Safawiyya) of the Zahediyya heritage; nor of the enrichment of the Safawiyya from the beginning, not only thanks to "generous donations" (p. 1-2). Curses on "the first three caliphs" (p. 4) did not spare the Ottomans. Nothing is said about the origin (the Mar'ašĩs of Māzandarān) of Šāh 'Abbās's mother, Mahd-e Owliyā (p. 16, 22, 24, 48). The comment on 'Abbās's conduct toward Jews, whom he compelled to wear "a visible warning" (p. 233), makes no mention of his cruelty toward their "mullas". Despite its defects (See the full review in St. Ir. 40/1, 2011), this well-written, agreeably illustrated book amounts to more than an ordinary biography of a great Persian king. 


\section{AUTHORS}

JEAN CALMARD

CNRS - EPHE, Paris 